Navigation Physics 3(1)(2021)
Navigation Physics
Journal of Physics Education

\title{
Analisis Pembelajaran Daring Pada Materi Dinamika Partikel Ditinjau Dari Komunikasi Matematis
}

\author{
Titin Supriyatin ${ }^{1 *}$, Dwi Aprillia Setia Asih ${ }^{1}$ dan Avini Nurazhimah Arfa ${ }^{2}$ \\ ${ }^{1}$ Program Studi Pendidikan Biologi Universitas Indraprasta PGRI \\ ${ }^{2}$ Program Studi Teknik Informatika Universitas Indraprasta PGRI \\ * E-mail: titinsupriyatin06@gmail.com
}

\begin{tabular}{ll}
\hline Info Artikel & Abstract \\
\hline Sejarah Artikel: & This study aims to analyze the achievement of each indicator that measures \\
Diterima April 2021 & students' mathematical understanding abilities in basic physics courses on particle \\
Disetujui Juni 2021 & dynamics material. This research is a qualitative descriptive study that seeks to \\
Dipublikasikan Juni 2021 & describe theanalysis of students' mathematical understanding abilities. The research \\
& subjects were 6 class 3 semester students of biology education consisting of 198 \\
Keywords: & students. The data collection method used includes tests of students' mathematical \\
Analysis, online learning, mathematical & understanding abilities in basic physics courses which include particle dynamics \\
communication. & material. Based on the results of the study, it was concluded that the level of ability \\
& of biology education students in basicphysics courses was as follows: (1) Students \\
& already had the ability to solve problems was good enough on particle dynamics \\
& material from questions 1 to 5 had an average percentage of 56.2\%, (2) Students \\
& have reasoning abilities (reasoning on particle dynamicsmaterial from questions 1 to \\
& 5 have an average percentage of 14.4\%, (3) Students have communication skills \\
(communication) on particle dynamics material from questions 1 to 5 have The & average percentage is $12.2 \%,(4)$ students have the ability to make connections to the \\
dynamic material of particles from questions 1 to 5 , have an average percentage of \\
12.4\%; (5) students have representation ability) on the particle dynamics material \\
from questions 1 to 5 has an average percentage of 4.8\%.
\end{tabular}

How to Cite: Supriyatin, T., Asih, D. A. S., \& Arfa, A. N. (2021). Analisis Pembelajaran Daring Pada Materi Dinamika Partikel Ditinjau Dari Komunikasi Matematis. Navigation Physics: Journal of Physics Education, 3 (1), $45-52$.

\section{PENDAHULUAN}

Penyebaran virus corona atau COVID-19 telah memberikan tantangan tersendiri bagi lembaga pendidikan di Indonesia.Untuk mengantisipasi penularan virus tersebut pemerintah mengeluarkan kebijakan seperti social distancing, physical distancing, hingga pembatasan sosial berskala besar (PSBB).Kondisi ini mengharuskan masyarakat untuk tetap diam dirumah, belajar, bekerja, dan beribadah di rumah. Akibat dari kebijakan tersebutmembuat sektor pendidikan seperti sekolah maupun perguruan tinggi menghentikan proses pembelajaran secara tatap muka. Sebagai gantinya, proses pembelajaran dilaksanakan secara daring yang bisa dilaksanakan dari rumah masing-masing. Sesuai dengan Surat Edaran Mendikbud Nomor 4 tahun 2020 tentang pelaksanaan kebijakan pendidikan dalam masa darurat penyebaran coronavirus disease (COVID-19) menganjurkan untuk melaksanakan proses belajar dari rumah melalui pembelajaran daring. Kesiapan dari pihak penyedia layanan maupun peserta didik merupakan tuntutan dari pelaksanaan pembelajaran daring. Pelaksanaan pembelajaran daring ini memerlukan perangkat pendukung seperti komputer atau laptop,handphone dan alat bantu lain sebagai perantara yang tentu saja semua itu harus terhubung dengan koneksi internet.Pembelajaran daring juga dilaksanakan pada mahasiswa semester 3 pendidkan biologi khususnya materi dinamika partikel melalui grup watshap, materi ini membutuhkan kemampuan komunikasi matematis pada pemahamannya .

Kemampuan berkomunikasi dengan orang lain merupakan salah satu kunci kesuksesan dari seseorang. Begitu pula dalam proses pembelajaran, apabila peserta didik tidak mampu menjalin komunikasi dengan sesama peserta didik ataupun dengan pendidik maka proses pembelajaran akan berlangsung kurang optimal. Hal ini menunjukkan bahwa kemampuan untuk berkomunikasi merupakan komponen yang penting dalam proses pembelajaran, termasuk juga dalam pembelajaran matematika. 
Matematika merupakan bagian dari ilmu pengetahuan yang turut memberikan sumbangan signifikan terhadap perkembangan ilmu pengetahuan dan pembangunan sumber daya manusia.Matematika juga memiliki peranan penting dalam pemenuhan kebutuhan praktis danpemecahan masalah dalam kehidupan sehari-hari, selain itu matematika juga dapat berperan sebagai bahasa atau alat komunikasi. Ibrahim (2008) mengatakan bahwa matematika adalah bahasa karena matematika merupakan sekumpulan simbol yang memiliki makna. Komunikasi matematis merupakan suatu cara siswa untuk menyatakan gagasangagasan matematika secara lisan maupun tertulis, baik dalam bentuk gambar, tabel, diagram maupun demonstrasi (Priyanto, dkk. dalam Hodiyanto. 2017). Peserta didik yang memiliki kemampuan untuk mengkomunikasikan ide atau gagasan matematisnya dengan baik cenderung mempunyai pemahaman yang baik terhadap konsep yang dipelajari dan mampu memecahkan permasalahan yang berkaitan dengan konsep yang dipelajari NCTM (2000). Peserta didik belum tentu memahami informasi yang mereka terima terkait konsep matematika karena karakteristik matematika yang sarat dengan istilah dan simbol. Menurut Cotton (2008) peserta didik dapatmengoptimalkan pemahaman mereka terhadap suatu konsep matematis dengan cara berpikir dan bernalar kemudian mengkomunikasikan ide mereka. Selain dengan cara mengkomunikasikan, mendengarkan penjelasan orang lain juga dapat mengoptimalkan pemahaman mereka. Mengkomunikasikan ide dapat dilakukan dengan dua cara, yaitu secara lisan maupun tertulis. Peserta didik harus berusaha agar tidak menimbulkan kesalahpahaman ketika mengkomunikasikan suatu konsep matematis. Melalui komunikasi, siswa dapat merenungkan dan mengklarifikasi ide-ide mereka, pemahaman mereka terhadap hubungan matematis, dan argument matematis mereka (Ontario Ministry of Education, 2005). Kemampuan komunikasi matematis merupakan salah satu standar proses dalam pembelajaran matematika juga dalam pembelajaran fisika dasar karena matematika sangat erat kaitannya dengan fisika dasar. Seperti yang diungkapkan dalam Principles \& Standards for School Mathematics (NCTM, 2000) yaitu standar proses dalam pembelajaran matematika meliputi kemampuan pemecahan masalah (problem solving), kemampuan penalaran (reasoning), kemampuan komunikasi (communication), kemampuan membuat koneksi (connection), dan kemampuan representasi (representation).

Gardner (Hiebert dan Carpenter, 1992) menyatakan bahwa pemahaman merupakan salah satu aspek dasar yang diperlukan saat pembelajaran berlansung, sehingga model pembelajaran yang digunakan pada saat itu harus memperdulikam persoalan mengenai pemahaman. Sejalan dengan Bloom (Ruseffendi, 1991) yang menyatakan bahwa terdapat tiga jenis pemahaman: 1) Pengubahan (translation),yaitu siswa mampu merubah soal yang menggunakan kata-kata ke dalam simbol dan begitujuga sebaliknya. 2) Pemberian (interpretation), yaitu mampu mengindetifikasi suatu persamaan yang ada 3) Pembuatan ekstrapolasi (extrapolation), misalnya mahasiswa mampu memperkirakan suatu kecondongan yang terdapat pada suatu diagram atau gambar tertentu.

Sementara itu, menurut pendapat Hiebert dan Carpenter (1992) mengklasifikasikan pemahaman matematis secara dikhotomi antara pemahaman prosedural dan pemahaman konseptual. Pemahaman konseptual mendukung daya ingat, karena fakta-fakta dan metode yangdipelajari saling berkaitan, mereka akan lebih mudah dalam mengingat dan menggunakannya kembali, serta mereka dapat mengkonstruksi ulang ketika lupa (Hiebert dan Carpenter, 1992). Pemahaman prosedural adalah pengetahuan tentang simbol untuk merepresentasikan ide matematika serta aturan dan prosedur yang digunakan dalam menyelesaikan tugas yangterkait dengan simbol-simbol. Hal ini berarti mahasiswa dapat mengetahui apa yang dilakukan dan mengapa alasan melakukan hal tersebut, jadi mahasiswa bukan sekedar mengerjakan soal sesuai aturan saja.Akan tetapi juga dapat memahami alasannya. Sedangkan definisi yang kedua adalah aturan yang tak beralasan. Mengerjakan soal dengan prosedur, namun tidak memahami apa yang dikerjakannya tersebut,hal ini mungkin mahasiswa terkait hanya mengikuti contoh yang sebelumnya diberikan oles seorang dosen. Dari hasil observasi di kelas saat mahasiswa melakukan pembelajaran secara daring sangat sulit untuk mengetahui apakah mahasiswa meniliki kemampuan komunikasi matematis dengan baik atau tidak. Untuk menyelidiki apakah pada pembelajaran daring seperti saat ini kemampuan komunikasi matematis pada pembelajaran fisika dasar dimiliki oleh mahasiswa, maka dilakukan survey terhadap mahasiswa saat pembelajaran daring.

\section{METODE PENELITIAN}

Pada penelitian ini metode yang digunakan adalah metode penelitian deskriptif kualitatif. Sukardi (2008) menyatakan bahwa penelitian deskriptif merupakan penelitian yang menggambarkan aturan atau menginterpretasikan objek sesuai dengan apa adanya, dimana peneliti ingin mengungkapkan kemampuan pemahaman komunikasi matematis mahasiswa.

Penelitian kualitatif merupakan penelitian yang digunakan untuk menyelidiki, menemukan, menggambarkan, dan menjelaskan kualitas atau keistimewaan dari pengaruh social yang tidak dapat dijelaskan, diukur atau digambarkan melalui pendekatan kuantitaif (Saryono, 2010). Peneliti memulai 
penelitiannya dengan mengumpulkan informasi sebanyak mungkin dari partisipan, lalu membentuk informasi inimenjadi kategori-kategori atau tema-tema tertentu (Creswell, 2012). Tujuan penelitian kualitatif pada umumnya mencakup informasi tentang fenomena utama yang dieksplorasi dalam penelitian, partisipan penelitian, dan lokasi penelitian (Creswell, 2012). Penelitian kualitatif digunakan untuk mendapatkan analisis data yang mendalam dan bermakna. Dengan maksud mendeskripsikan fenomena, dimana peneliti mengungkapkan pemahaman matematis mahasiswa dalam mata kuliah fisika dasar pada materi dinamikapartikel.

Penelitian dilakukan di Universitas Indraprasta semester genap PGRI Semester gasal tahun 2020/2021. Subjek penelitian adalah mahasiswa Program Studi Pendidikan Biologi Universitas Indraprasta PGRI semester 3sebanyak 6 kelas yang terdiri dari 198 mahasiswa.

Tes yang digunakan dalam penelitian ini adalah tes soal pemahaman matematis yang terdiri atas 5 soal essay. Soal tersebut mencakup indikator pemahaman matematis yaitu: Kemampuan menggunakan, memanfaatkan, dan memilih prosedur atau operasi tertentu, kemampuan mengaplikasikan konsep atau algoritma pemecahan masalah, dan Kemampuan mengklasifikasikan objek-objek menurut sifat- sifat tertentu.

Soal pertama untuk mengukur kemampuan mahasiswa dalam menggunakan, memanfaatkan, dan memilih prosedur dalam menentukanpercepatan benda jika gaya dan massa benda diketahui. Soal nomor duauntuk mengukur kemampuan mahasiswa dalam menentukan. Panjang talisuatu benda .Soal nomor tiga untuk mengukur kemampuan mahasiswadalam memecahan masalah dalam menentukan gaya suatu benda Soal nomor empat untuk mengukur kemampuan mahasiswa dalam menentukan kecepatan benda jika benda mengalami tumbukan. Soal nomor lima untuk mengukur kemampuan mahasiswa dalam menentukannilai kecepatan benda jika massa, gaya dan sudut elivasi benda diketahui benda jika massa, gaya dan sudut elivasi benda diketahui.

\section{HASIL DAN PEMBAHASAN}

Setelah menganalisis data yang diperoleha dari jawaban UAS mata kuliah fisika dasar mahasiswa semester 3 pendidikan biologi universitas indraprasta PGRI dapat diketahui skor pemahaman matematis sebagai berikut:

1. Analisis Kemampuan mahasiswa dalam memecahkan masalahdalam menjawab soal tes yang diberikan.

\section{Kerjakan soal-soal berikut dengan benar dan tepat.}

1. Gaya (F) sebesar $16 \mathrm{~N}$ bekerja pada sebuah benda yang massanya $\mathrm{m}_{1}$ menyebabkan percepatan $a_{1}$ sebesar $10 \mathrm{~m} / \mathrm{s}^{2}$. Jika $\mathrm{F}$ bekerja pada benda bermassa $\mathrm{m}_{2}$ maka percepatan yang ditimbulkannya yaitu $4 \mathrm{~m} / \mathrm{s}^{2}$. Jika $\mathrm{F}$ bekerja pada benda bermassa $\mathrm{m}_{1}+\mathrm{m}_{2}$, maka percepatan benda itu yaitu ...

$\pi$

Gambar 1.Soal tes nomor 1 yang diberikan ke mahasiswa

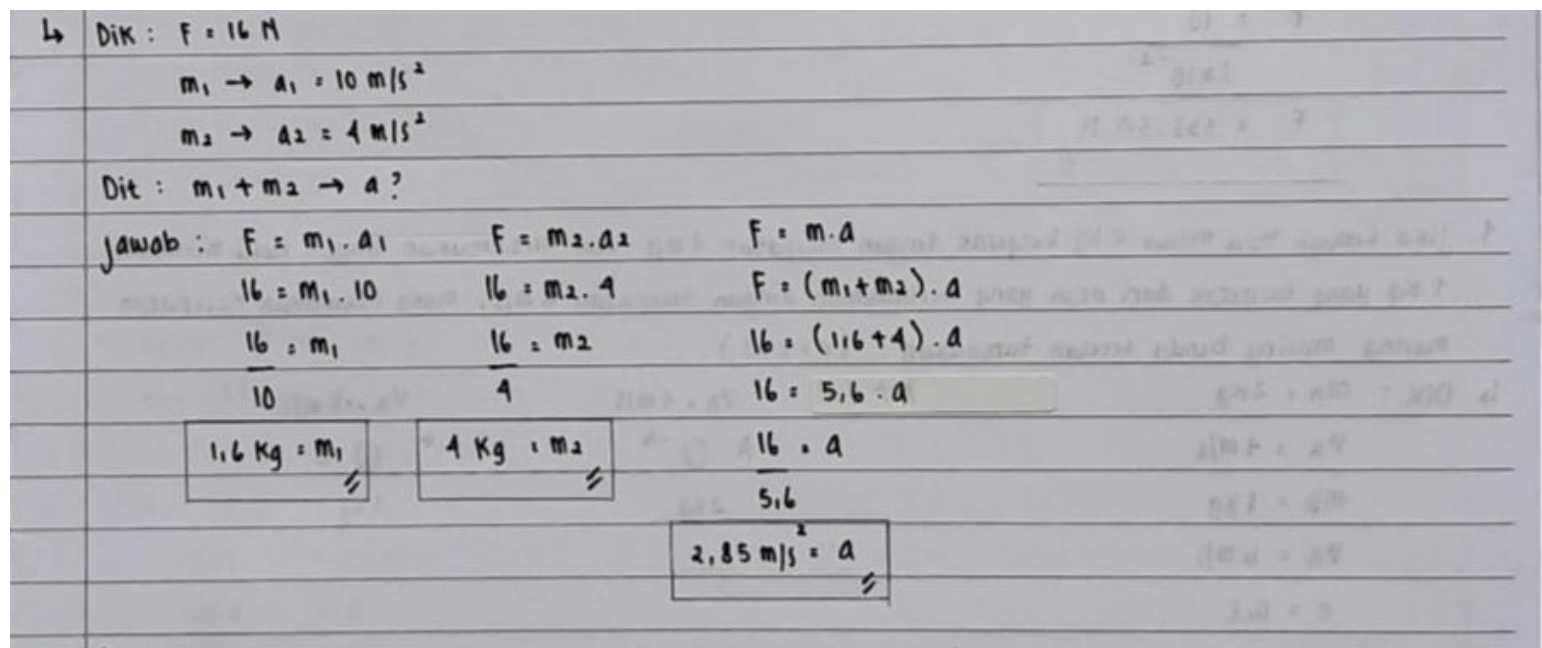

Gambar 2. Jawaban mahasiswa 
Berdasarkan gambar 2. memperlihatkan bahwa mahasiswa mempunyai kemampuan dalam mecahkan masalah , hal itu bisa terlihat dari mahasiswa mampu memahami penulisan simbol-simbol dan menuliskan satuan dari gaya,massa dan percepatan. Selain itu mahasiswa juga mampu memilih formula atau rumus yang harus digunakan dalam menyelesaikan soal yang telah diberikan. Tetapi jawaban mahasiswa tidak disertai gambar dari soal yang diberikan sehingga dalam hal ini mahasiswa belum mengerti dalam mengkomunikasikannya dalam bentuk gambar.skor yang diperoleh mahasiswa jika menulis diketahui, penulisan simbol serta satuan benar maka mahasiswa dapat mendapat skor 5 , jika disertai gambar makan mahasiswa mendapatkan skor 8, jika formula yang digunkan benar dan hasil akhir benar maka akan memperoleh skor 20. Jadi jawaban dari mahasiswa pada gambar 2 hanya memperoleh skor 17 karena tidak disertai gambar penyelesaiannya.

2. Analisis Kemampuan penalaran ( reasoning) mahasiswa dalam menjawab soal tes yang diberikan

2. Pada gambar di samping, terdapat batang homogen sepanjang $3 \mathrm{~m}$ dengan berat $200 \mathrm{~N}$. Di atasnya, diletakkan kotak dengan berat $300 \mathrm{~N}$. Sudut yang dibentuk ujung batang dengan tali pengikat adalah $30^{\circ}$. Tali sanggup menahan tegangan maksimum sebesar $500 \mathrm{~N}$. Berapakah posisi X terjauh sebelum tali putus?

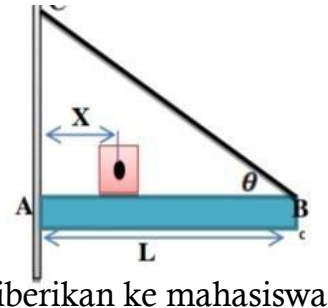

Gambar 3. Soal tes nomor 2 yang diberikan ke mahasiswa

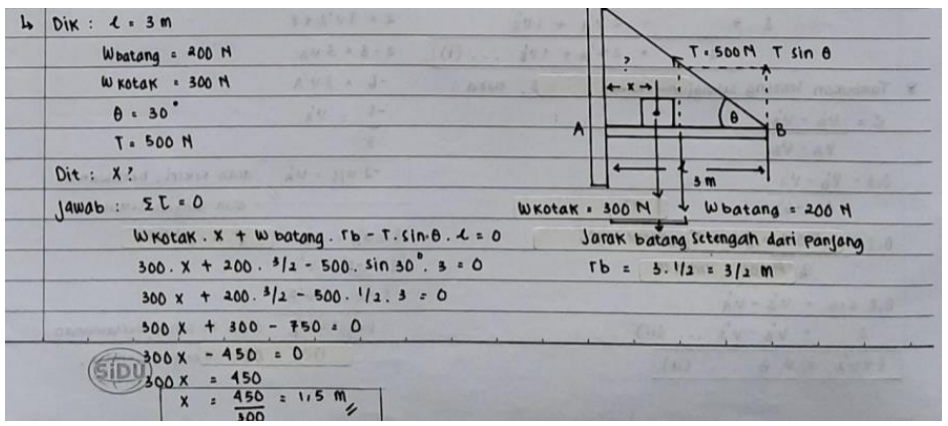

Gambar 4. Jawaban mahasiswa soal nomor 2

Berdasarkan gambar 4. Memperlihatkan bahwa mahasiswa mempunyai kemampuan dalam mecahkan masalah, hal itu bisa terlihat dari mahasiswa mampu memahami penulisan simbol-simbol dan menuliskan satuan dari panjang tali, berat serta sudut elivasi. selain itu mahasiswa juga mampu memilih formula atau rumus yang harus digunakan dalam menyelesaikan soal yang telah diberikan. Kemampuan nalar serta kemampuan mengkomunikasikan serta mampu mempresentasikan soaljuga telah dikuasai hal ini terbukti dari jawaban mahasiswa telah di sertai gambar dari soal yang diberikan sehingga dalam hal ini mahasiswa belum mengerti dalam mengkomunikasikannya dalam bentuk gambar. Skor yang diperoleh mahasiswa jika menulis diketahui, penulisan simbol serta satuan benar maka mahasiswa dapat mendapat skor 5, jika disertai gambar maka mahasiswa mendapatkan skor 8 , jika formula yang digunkan benar dan hasil akhir benar maka akan memperoleh skor 20. Jadi jawaban dari mahasiswa memperoleh skor 20.

3. Analisis Kemampuan Komunikasi (communication) mahasiswa dalam menjawab soal tes yang diberikan.

3. Sebuah benda massanya $0,20 \mathrm{~kg}$ jatuh bebas dari ketinggian $5 \mathrm{~m}$ ke hamparan pasir. Jika benda tersebut masuk sedalam $3 \mathrm{~cm}$ ke dalam pasir sebelum berhenti, maka gaya rata-rata yang dilakukan pasir untuk menghambat benda besarnya sekitar....

Gambar 5 Soal tes nomor 3 yang diberikan ke mahasiswa 


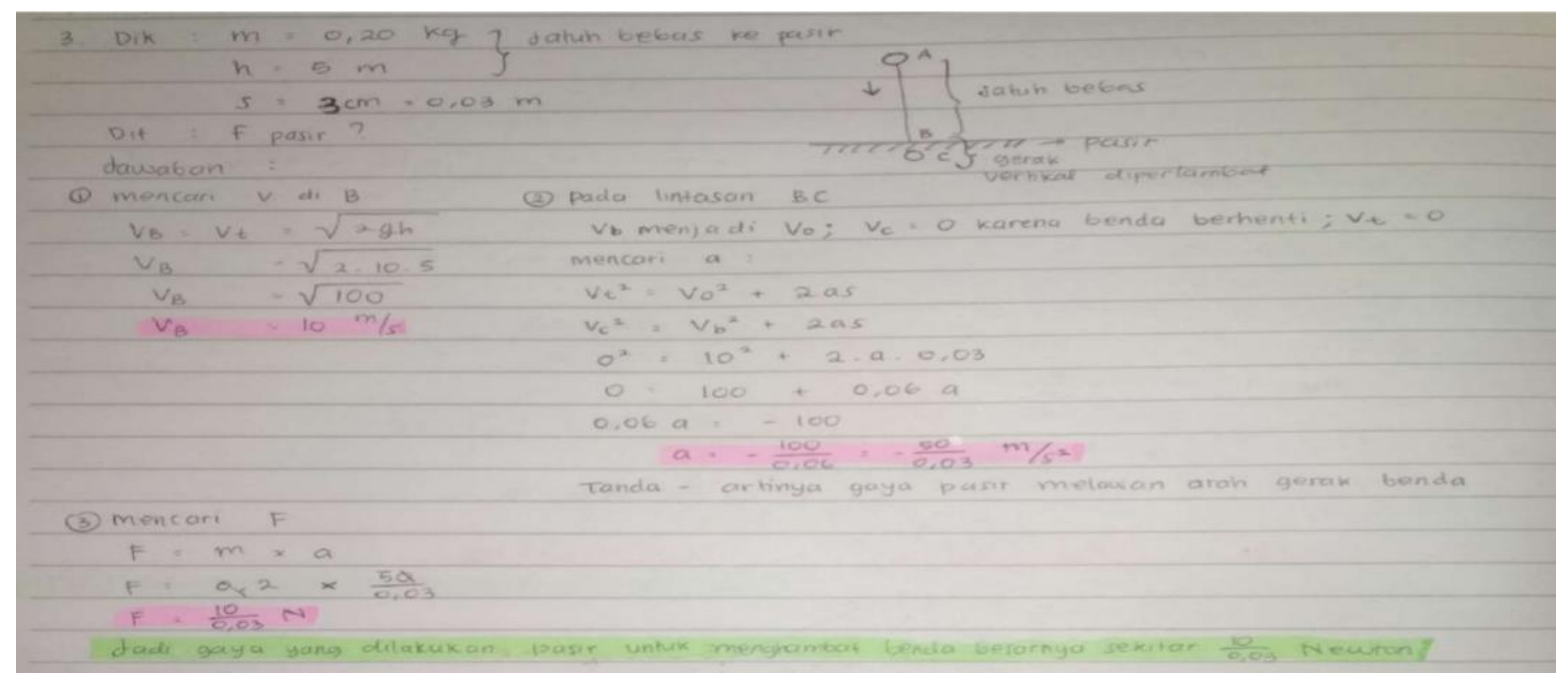

Gambar 6. Jawaban mahasiswa soal nomor 3

Berdasarkan gambar 6. Memperlihatkan bahwa mahasiswa mempunyai kemampuan dalam mecahkan masalah, hal itu bisa terlihat dari mahasiswa mampu memahami penulisan simbol-simbol dan menuliskan satuan dari massa, ketinggian dan kedalaman. Selain itu mahasiswa juga masih salah dalam memilih formula atau rumus yang harus digunakan dalam menyelesaikan soal yang telah diberikan serta kemampuan nalar mahisiswa juga belum terlihat dari soal nomor 3 ini, hal ini terlihat dari proses mencari kecepatan terlebih dahulu, padahal secara nalar jika benda dijatuhkan secara bebas maka kecepatan sudah tidak perlu dicari lagi. Hal ini akan terlihat sia-sia belaka. Kemampuan mengkomunikasikan serta mampu mempresentasikan soal juga telah dikuasai hal ini terbukti dari jawaban mahasiswa telah di sertai gambar dari soal yang diberikan sehingga dalam hal ini mahasiswa sudah mengerti dalam mengkomunikasikannya dalam bentuk gambar.skor yang diperoleh mahasiswa jika menulis diketahui, penulisan simbol serta satuan benar maka mahasiswa dapat mendapat skor 5, jika disertai gambar makan mahasiswa mendapatkan skor 8 , jika formula yang digunkan benar dan hasil akhir benar maka akan memperoleh skor 20. Jadi jawaban dari mahasiswa di atas memperoleh skor 10 karena hasil akhir dan penggunaan formula masih ada kesalahan.

4. Analisis Kemampuan membuat koneksi(connection) mahasiswadalam menjawab soal tes yang

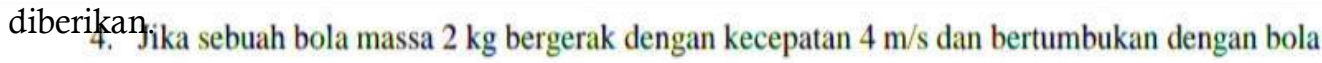

bermassa $1 \mathrm{~kg}$ yang bergerak dari arah yang berlawanan dengan kecepatan $6 \mathrm{~m} / \mathrm{s}$, maka berapakah kecepatan masing-masing benda setelah tumbukan? $(\mathrm{e}=0,8)$

Gambar 7. Soal nomor 4 tes yang diberikan ke mahasiswa

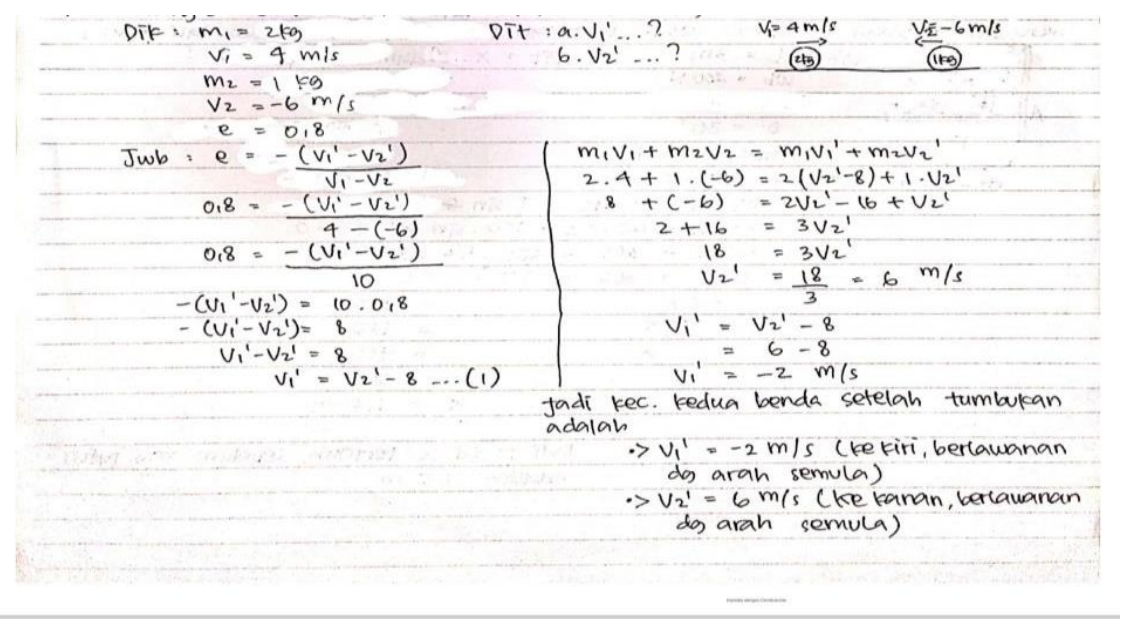

Gambar 8. Jawaban mahasiswa soal nomor 4 
Berdasarkan gambar 8. Memperlihatkan bahwa mahasiswa mempunyai kemampuan dalam mecahkan masalah, hal itu bisa terlihat dari mahasiswa mampu memahami penulisan simbol-simbol dan menuliskan satuan dari massa dan kecepatan. Selain itu mahasiswa juga sudah memahami dalam memilih dan menggunakan formula atau rumus yang harus digunakan dalam menyelesaikan soal yang telah diberikan serta kemampuan nalar mahasiswa juga sudah terlihat dari soal nomor 4 ini. Kemampuan mengkomunikasikan serta mampu mempresentasikan soal juga telah dikuasai hal ini terbukti dari jawaban mahasiswa telah di sertai gambar dari soal yang diberikan sehingga dalam hal ini mahasiswa sudah mengerti dalam mengkomunikasikannya dalam bentuk gambar. Tetapi mahasiswa belum mempunyai kesalahan dalam membuat koneksi atau menghubungkan antara tanda arah gaya yang berlawanan, hal ini terbukti dari jawaban mahasiswa jika hasilnya negatif artinya gaya tersebut bergerak ke arah kiri jadi hasilnya tetap positif di hasil akhir. Skor yang diperoleh mahasiswa jika menulis diketahui, penulisan simbol serta satuan benar maka mahasiswa dapat mendapat skor 5 , jika disertai gambar makan mahasiswa mendapatkan skor 8 , jika formula yang digunakan benar dan hasil akhirbenar maka akan memperoleh skor 20. Jadi jawaban dari mahasiswa di gambar 8. Memperoleh skor 18 karena hasil akhirnya harusnya tidak perlu ada tanda negatif lagi, cukup diberi keterangan bahwa gaya bergerak ke arah kiri.

5. Kemampuan representasi (representation) mahasiswa dalammenjawab soal tes yang diberikan.

5. Sebuah balok massanya $2 \mathrm{~kg}$ yang terletak pada bidang datar kasar diberi gaya konstan sebesar $10 \mathrm{~N}$ membentuk sudut $37^{\circ}$ terhadap bidang horizontal. Jika koefisien gesek antara balok dan lantai 0,4 maka besar kecepatan benda setelah 5 detik adalah.... ( $\sin 37^{\circ}=0,6$ dan $\left.\cos 37^{\circ}=0,8\right)$

Gambar 9. Soal nomor 4 tes yang diberikan ke mahasiswa

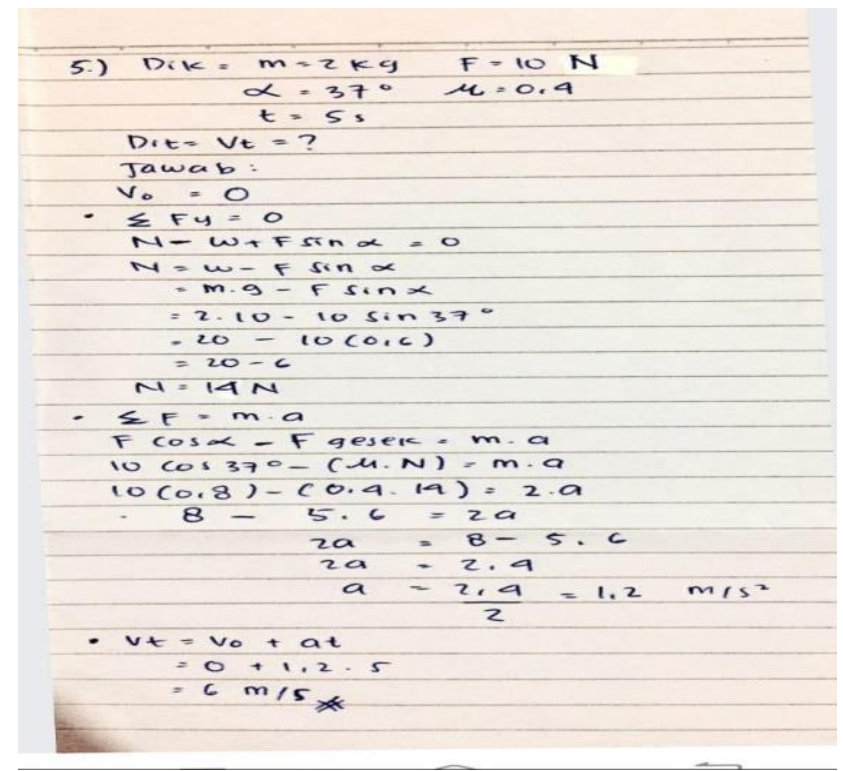

Gambar 10. Jawaban mahasiswa soal nomor 5

Berdasarkan gambar 10. Memperlihatkan bahwa mahasiswa mempunyai kemampuan dalam mecahkan masalah, hal itu bisa terlihat dari mahasiswa mampu memahami penulisan simbol-simbol dan menuliskan satuan dari gaya konstan, massa dan sudut elivasi dan kecepatan. Selain itu mahasiswa juga mampu memilih formula atau rumus yang harus digunakan dalam menyelesaikan soal yang telah diberikan. Tetapi jawaban mahasiswa tidak disertai gambar dari soal yang diberikan sehingga dalam hal ini mahasiswa belum mengerti dalam mempresentasikan soal tersebut dalam bentuk gambar. Skor yang diperoleh mahasiswa jika menulis diketahui,penulisan simbol serta satuan benar maka mahasiswa dapat mendapat skor 5, jika disertai gambar makan mahasiswa mendapatkan skor 8 , jika formula yang digunkan benar dan hasil akhir benar maka akan memperoleh skor 20. Jadi jawaban dari mahasiswa tersebut hanya memperoleh skor 17 karena tidak disertai gambar penyelesaiannya.

Dilihat dari hasil analisis jawaban mahasiswa semester 3 biologi didapatkan presentase hasil jawaban mahasiswa secara keseluruhan, yang dapat dilihat pada tabel 1 . 
Berdasarkan hasil Analisis data yang didapat untuk melakukan pengukuran kemampuan komunikasi matematis mahasiswa sejalan dengan pendapat Kadir (2008) mengungkapkan bahwa pengukuran kemampuan komunikasi matematis siswa dilakukan dengan pemberian skor terhadap kemampuan siswa dalam pemberian jawaban soal dengan menggambar (drwing), membuat ekspresi matematik, dan menuliskan jawaban dengan bahasa sendiri.

Tabel 1. Presentase hasil jawaban mahasiswa secara keseluruhan

\begin{tabular}{lrrrrrl}
\hline \multicolumn{1}{c}{ Indikator } & \multicolumn{3}{c}{ No Soal (\%) } & \multicolumn{2}{c}{ Rata-rata } \\
\hline $\begin{array}{llllll}\text { Kemampuan pemecahan masalah(problem } \\
\text { solving) }\end{array}$ & $65 \%$ & $48 \%$ & $55 \%$ & $56 \%$ & $57 \%$ & $56,2 \%$ \\
Kemampuan penalaran ( reasoning) & $10 \%$ & $16 \%$ & $13 \%$ & $17 \%$ & $16 \%$ & $14,4 \%$ \\
Kemampuan komunikasi(communication) & $7 \%$ & $20 \%$ & $18 \%$ & $6 \%$ & $10 \%$ & $12,2 \%$ \\
Kemampuan membuatkoneksi(connection) & $13 \%$ & $10 \%$ & $11 \%$ & $14 \%$ & $14 \%$ & $12,4 \%$ \\
Kemampuan representasi (representation) & $5 \%$ & $6 \%$ & $3 \%$ & $7 \%$ & $3 \%$ & $4,8 \%$ \\
\hline
\end{tabular}

Bersadarkan tabel 1. Dapat dilihat bahwa presentase rata-rata indikator dari komunikasi matematis tertinggi yaitu kemampuan pemecahan masalah (Problem solving) dan presentase rata-rata indikator terendahnya yaitu kemampuan representasi (representation). Hal tersebut dilihat dari proses pembelajaran dan hasil pengerjaan soal tes yang diberikan bahwa mahasiswa mampu memecahkan masalah dengan benar namun mahasiswa lemah dalam merepresentasikan jawabannya dilihat dari jawaban yang kurang runtut dalam membahas serta banyak yang tidak dilengkapi gambar sebagai penguat jawaban.

Pemberian soal uraian pada penelitian ini dapat mengidentifikasi kemempuan komunikasi matematis mahasiswa dalam menyelesaikan soal-soal dinamika partikel yang telah disesuaikan dengan indikator dari kemampuan komunikasi matematis. Mahasiswa menjawab dengan menggambarkan aspek ekspresi matematika dengan menggunakan simbol matematika dan dengan bahasanya sendiri yang merupakan gambaran dari aspek menulis atau kemampuan mengkomunikasikan. Hal ini sejalan dengan pendapat Ansari (2012) untuk mengukur kemampuan komunikasi matematis dalam pembelajaran dapat dilakukan dengan soal uraian yang bisa mengungkapkan kemampuan komunikasi matematis.

\section{PENUTUP}

Berdasarkan hasil data dan pembahasan, dapat disimpulkan, (1) Mahasiswa sudah memiliki kemampuan dalam memecahkan masalah sudah cukup baik pada materi dinamika partikel dari soal 1 sampai 5 mempunyai presentase rata-rata $56,2 \%$, (2) Mahasiswa mempunyai kemampuan penalaran (reasoning pada materi dinamika partikel dari soal 1 sampai 5 mempunyai presentase rata-rata sebesar $14,4 \%$, (3) Mahasiswa mempunyai Kemampuan komunikasi(communication) pada materi dinamika partikel dari soal 1 sampai 5 mempunyai presentase rata-rata sebesar $12,2 \%,(4)$ mahasiswa mempunyai kemampuan membuat koneksi (connection) pada materi dinamika partikel dari soal 1 sampai 5 mempunyai presentase rata-rata sebesar $12,4 \%$; (5) mahasiswa mempunyai Kemampuan representasi( representation) pada materi dinamika partikel dari soal 1 sampai 5 mempunyai presentase rata-rata 4,8\%. Berdasarkan kesimpulan yang diperoleh, untuk meingkatkan kemampuan pemahaaman komunikasi matematis mahasiswa hendaknya pada mata kuliah fisika dasar materi dinamika partikel mahasiswa hendaknya banyak diberikan latihan soal yang melibatkan dalam kehidupansehari-hari dalam memahaminya.

\section{DAFTAR PUSTAKA}

Ansari, B. I. 2012. Komunikasi Matematik dan Politik. Banda Aceh: Yayasan Pena

Creswell, John W. 2012. Research Design Pendekatan Kualitatif, Kuantitatif dan Mixed. Yogyakarta:Pustaka Pelajar.

Depdiknas. 2006. Peraturan Menteri Pendidikan Nasional Nomor 22 Tahun 2006 tentang Standar Isi. Jakarta: Direktorat Jenderal Manajemen Pendidikan Dasar dan Menengah.

Hiebert, J., Carpenter, T. P. 1992. Learning and Teaching with Understanding.Dalam D. A. Grows (Ed.), Handbook of Research on Mathematics Teaching and Learning. New York: Macmillan Publishing Company. 
Cotton \& Hirschfeld, Kimberly. (2008). Mathematical Communication, Conceptual Understanding, and Students' attitudes Toward Mathematics.Math in the Middle Institute Partnership Action Research Project Report: University of Nebraska-Lincoln

Hodiyanto. (2017). Kemampuan Komunikasi Matematis dalam Pembelajaran Matematika. AdMathEdu. 7(1).9-18.

Ibrahim, Suparni. 2008. Strategi Pembelajaran Matematika. Yogyakarta: Bidang Akademik

Kadir. 2008. Kemampuan Komunikasi Matematik dan Keterampilan Sosial Siswa dalam Pembelajaran Matematika. Seminar Nasional Matematika pp. 339-350. UNY: Yogyakarta

NCTM. 2000. Principles and Standards for School Mathematics. Reston, VA: The National Council of Teachers of Mathematics, Inc.

Ontario Ministry of Education. (2005). The Ontario Curriculum Grades 1- 8:Mathematics.Ontario Ministry of Education: Ontario. Diakses dari http://www.edu.gov.on.ca/eng/curriculum/elementary/math18curr.pdf.pada tanggal 21 Februari 2021, Jam 20.38 WIB

Ruseffendi, E. T. (1991). Penelitian Pendidikan dan Hasil Belajar Siswa Khususnya dalam Pengajaran Matematika. Bandung: Tarsito.

Saryono. 2010. Metodologi Penelitian Kualitatif dalam Bidang Kesehatan. Yogyakarta: NuhaMedika.

Sukardi. 2008. Metodelogi Penelitian Pendidikan. Bumi Aksara : Jakarta. 